\title{
Probabilities for Profitable Fungicide Use Against Gray Leaf Spot in Hybrid Maize
}

\author{
G. P. Munkvold, C. A. Martinson, J. M. Shriver, and P. M. Dixon
}

First, second, and third authors: Department of Plant Pathology, Iowa State University, Ames 50011; and fourth author: Department of Statistics, Iowa State University, Ames 50011.

Accepted for publication 18 January 2001.

\begin{abstract}
Munkvold, G. P., Martinson, C. A., Shriver, J. M., and Dixon, P. M. 2001. Probabilities for profitable fungicide use against gray leaf spot in hybrid maize. Phytopathology 91:477-484.

Gray leaf spot, caused by the fungus Cercospora zeae-maydis, causes considerable yield losses in hybrid maize grown in the north-central United States and elsewhere. Nonchemical management tactics have not adequately prevented these losses. The probability of profitably using fungicide application as a management tool for gray leaf spot was evaluated in 10 field experiments under conditions of natural inoculum in Iowa. Gray leaf spot severity in untreated control plots ranged from 2.6 to $72.8 \%$ for the ear leaf and from 3.0 to 7.7 ( 1 to 9 scale) for wholeplot ratings. In each experiment, fungicide applications with propiconazole or mancozeb significantly reduced gray leaf spot severity. Fungicide treatment significantly $(P \leq 0.05)$ increased yield by as much

periment the probability of achieving a positive net return with one or two propiconazole applications, based on the mean yields and standard deviations for treated and untreated plots, the price of grain, and the costs of the fungicide applications. For one application, the probability ranged from approximately 0.06 to more than 0.99 , and exceeded 0.50 in six of nine scenarios (specific experiment/hybrid). The highest probabilities occurred in the 1995 experiments with the most susceptible hybrid. Probabilities were almost always higher for a single application of propiconazole than for two applications. These results indicate that a single application of propiconazole frequently can be profitable for gray leaf spot management in Iowa, but the probability of a profitable application is strongly influenced by hybrid susceptibility. The calculation of probabilities for positive net returns was more informative than mean separation in terms of assessing the economic success of the fungicide applications.
\end{abstract} as $1.65 \mathrm{t} / \mathrm{ha}$ with a single propiconazole application. There were significant $(P<0.05)$ correlations between gray leaf spot severity and yield. We used a Bayesian inference method to calculate for each ex-
Additional keywords: Bayesian statistics, corn, economic benefits, foliar disease.
Gray leaf spot, caused by Cercospora zeae-maydis Tehon \& Daniels, has become the most important foliar disease of hybrid maize in most of the north-central United States, as well as elsewhere in the world (38). Annual yield loss estimates have exceeded $\$ 100$ million in Iowa maize production for several years during the 1990s. Yield reductions ranging from 11 to $44 \%$ have been reported in Iowa, 24 to $69 \%$ in Virginia, and 29 to $65 \%$ in South Africa (38). The emergence of this disease in the United States accompanied the widespread abandonment of extended crop rotations and tillage of crop residue for management of foliar diseases in the maize-growing regions of the United States (13). Although sources of resistance to gray leaf spot have been identified $(3,5,10,25)$ and partial resistance exists in commercial hybrids $(17,29)$, yield losses can still occur even in the most resistant, currently available hybrids (9), and this disease is not under adequate control by resistance. Fungicides are used widely for gray leaf spot management in maize seed production, but rarely in grain production in the United States. Propiconazole has been the standard product used on maize in the United States since 1994.

Research on using fungicides for gray leaf spot management has been reported from the United States and South Africa (38). In South Africa, Ward et al. $(36,37)$ found that one or more fungicide applications were profitable in nearly every experiment. Several reports from Virginia (30-32), Ohio $(14,15)$, and Iowa (20) indicated that in some hybrids during some years, substantial yield

Corresponding author: G. P. Munkvold; E-mail address: munkvold@iastate.edu

Publication no. P-2001-0216-01R

(c) 2001 The American Phytopathological Society increases (as much as $6.3 \mathrm{t} / \mathrm{ha}$ ) could be achieved with only a single fungicide application. But other reports from Indiana (26), Kentucky $(34,35)$, and Ohio (16) have shown much less dramatic yield increases, and in some cases, yields were not significantly different between plots receiving fungicide applications and control plots. Fungicidal control of gray leaf spot and other foliar diseases in maize seed production (in which the crop value is more than 10 times higher than in grain production) is frequently profitable $(18,27,39)$, but these results are not directly applicable to grain production.

The efficient use of fungicides for management of foliar diseases in maize has been hampered by inadequate methods for assessing the profitability of fungicide applications. Decision tools such as economic injury levels (EIL) (22) have not been established for foliar diseases of maize. It can be difficult to apply these concepts to the management of maize foliar diseases. EIL calculation requires knowledge of the amount of damage (yield loss) per unit of pest population (or disease severity) and knowledge of the expected efficacy of the management input (22). It is assumed that these parameters and others are known with a high level of precision, and the EIL is calculated as a single value not associated with a probability. An action threshold is reached when it is estimated that actual injury will reach the EIL, and the management tactic (fungicide application) is employed (22). Unfortunately, the measurement of yield losses associated with specific gray leaf spot severity levels and the measurement of yield increases attributable to fungicide applications are not precise. Damage per unit of gray leaf spot severity can vary by as much as $100 \%$ between locations or hybrids (11). Calculation of EIL based on predicted disease control is not practical when damage per unit injury is so variable. 
Because of yield variability within experimental fields, yield increases with values that appear to exceed the cost of fungicide application frequently are not statistically significant. For example, in several studies on fungicidal control of gray leaf spot in the United States and South Africa, the least significant yield difference among treatments was reported as $>1.0(26), 1.2(15,32),>1.2$ (38), 1.3 (31), 1.4 (14), and $>2.0$ t/ha (34). In each of these examples, a yield increase of 0.3 to $0.9 \mathrm{t} / \mathrm{ha}$, which would appear to be sufficient to offset the cost of a single fungicide application, would not be statistically significant. These problems create a dilemma in development of disease management recommendations. The economic justification of a fungicide application is difficult to assess when the least significant difference among experimental treatments exceeds the "break-even" yield difference. An alternative is to use a Bayesian statistical technique $(2,33)$ to calculate the probability that a fungicide application results in a positive net return.

The objective of this study was to assess the profitability of fungicide applications for gray leaf spot control under conditions of natural inoculum. This question was investigated in field scenarios where the disease is typically encountered in Iowa, and a Bayesian inference method was used to calculate the probabilities that fungicide applications resulted in positive net returns for each experiment.

\section{MATERIALS AND METHODS}

Ten field experiments were conducted in several locations in 1995, 1996, and 1997. Experiments were conducted at the Iowa State University Southeast Research Farm (SERF) near Crawfordsville (Washington County) and in commercial production fields near Conrad (Marshall County) or Mount Pleasant (Henry County). No inoculations were performed. Fields were planted in early May to mid-May, except for field 8 in 1996 (planted 15 June), with plant populations of 69,000 to 76,000 per hectare and $0.76-\mathrm{m}$ row spacing. Experimental design was a randomized complete block, except in experiments involving two hybrids, in which the design was a split plot with hybrid as the main plot factor and fungicide treatment as the subplot factor. In most experiments, there was a 3-m buffer of maize plants between plots or subplots. Details of individual experiments are shown in Table 1.

In 1995, there were four experiments: two at SERF and one each near Conrad and Mount Pleasant. The hybrid at Conrad was 3394 (Pioneer Hi-Bred International Inc., Des Moines, IA), considered highly susceptible to gray leaf spot, and the hybrid at Mount Pleasant was DK591 (DeKalb Plant Genetics Inc., IL), considered susceptible. For SERF experiment 1, the hybrid was 3394 and for SERF experiment 2, the hybrid was 5677 (Cargill Hybrid Seeds Inc.), moderately susceptible to gray leaf spot.

TABLE 1. Field plot characteristics for gray leaf spot management experiments conducted in Iowa, 1995 to 1997

\begin{tabular}{|c|c|c|c|c|c|}
\hline Year & Experiment $^{\mathrm{w}}$ & Previous crop & Tillage $^{\mathrm{x}}$ & Replications & $\begin{array}{l}\text { Plot size } \\
(\text { row } \times \mathrm{m})^{\mathrm{y}}\end{array}$ \\
\hline \multirow[t]{4}{*}{1995} & SERF 1 & Maize & None & $4^{z}$ & $10 \times 19.8$ \\
\hline & SERF 2 & $\begin{array}{c}\text { Winter wheat/ } \\
\text { soybeans }\end{array}$ & None & 4 & $10 \times 15.2$ \\
\hline & Conrad & Maize & SFC & 6 & $14 \times 19.8$ \\
\hline & Mt. Pleasant & Maize & SFC & 6 & $14 \times 19.8$ \\
\hline \multirow[t]{4}{*}{1996} & SERF 8E & Maize & None & 6 & $10 \times 16.8$ \\
\hline & SERF 8W & Maize & None & 4 & $10 \times 16.8$ \\
\hline & SERF 10 & Soybeans & None & 4 & $10 \times 16.8$ \\
\hline & Conrad & Maize & SFC & 5 & $14 \times 16.8$ \\
\hline \multirow[t]{2}{*}{1997} & SERF & Maize & None & 5 & $10 \times 16.0$ \\
\hline & Conrad & Maize & SFC & 4 & $10 \times 16.0$ \\
\hline
\end{tabular}

${ }^{\mathrm{w}} \mathrm{SERF}=$ Iowa State University Southeast Research Farm, Crawfordsville.

${ }^{x} \mathrm{SFC}=$ spring field cultivation.

y Row spacing was $0.76 \mathrm{~m}$.

${ }^{\mathrm{z}}$ One replicate block was abandoned due to standing water.
There were five fungicide treatments in 1995, applied according to plant growth stage, including a nontreated control, propiconazole (Tilt 3.6E; Novartis Crop Protection Inc., Greensboro, NC), and mancozeb (Penncozeb 75DF; Elf Atochem NA Inc., Philadelphia). Table 2 provides descriptions of rates and timing. A spreader sticker, Latron B-1956, was added to the mancozeb spray mixture at $161 \mathrm{ml} / \mathrm{ha}$. Fungicides were applied with a Hagie highclearance sprayer (Hagie Manufacturing Co., Clarion, IA) with three TXVS-4 nozzles per row; one was directed over the row and two were on $61-\mathrm{cm}$ drops between the rows, directed at an angle to provide best coverage of the foliage. The sprayer traveled at $4.18 \mathrm{kph}$, and the nozzles delivered 140 liter/ha at $345 \mathrm{kpa}$. Although disease thresholds were not used as criteria for fungicide applications, symptoms were observed at the time of the applications. In each experiment, gray leaf spot severity was low (ranging from less than one to seven lesions per plant) at the time of the fungicide applications.

Gray leaf spot severity was assessed twice (R4-early dough stage and R5-early dent stage [24]) in each experiment according to two methods. The first method was an estimate of the percentage of diseased leaf tissue on the ear leaf and on the leaf above the ear of 10 arbitrarily selected plants per plot. The mean of the scores from the two leaves was calculated for each plant. This method and timing of disease assessment were reported as optimal for critical-point yield loss modeling for gray leaf spot (11). Ratings were made with the assistance of standard area diagrams developed for gray leaf spot (28); to further reduce inter-rater variability, raters were trained using computer software CornPro (F. Nutter, Iowa State University, Ames) (21). The second method was a whole-plot evaluation similar to those employed in breeding for resistance to foliar diseases in maize (39). Severity was assessed on a 1 to 9 scale in which $1=$ no disease or traces of disease, $3=$ lesions present on lower leaves but little or no disease above the ear leaf, $5=$ disease present on most leaves with some lower leaves dead, 7 = lower leaves dead and numerous lesions on all upper leaves, and $9=$ nearly all leaf tissue killed. All assessments within an experiment were made by a single rater. Only gray leaf spot was considered.

When grain moisture reached $22 \%$ or less, plots were measured and trimmed to $18.2 \mathrm{~m}$. Gaps of missing or lodged plants greater than $1 \mathrm{~m}$ long were measured and recorded in order to adjust yield calculations. The center eight rows of each plot were harvested with a plot combine equipped with an electronic balance. Grain weights were measured on the combine, and samples were taken for moisture determinations. Yields were calculated with corrections for moisture content (standardized to $15.5 \%$ ), which was measured with a moisture tester (Dole 400; Eaton Corp., Carol Stream, IL). Yields were not measured at Mount Pleasant because of hail damage. Yields were measured only in SERF experiment 1 and Conrad.

In 1996, there were four field experiments: three were located at SERF (fields 8 and 10) and one was located at Conrad. A splitplot experiment was established in field 10 with two hybrids, Pioneer hybrid 3394 (highly susceptible) and Pioneer hybrid 3348 (moderately resistant). At Conrad, Pioneer hybrids 3335 and 3489 (both intermediate in susceptibility to gray leaf spot) were planted. In field 8 at SERF, two separate experiments were established in the east $(8 \mathrm{E})$ and west $(8 \mathrm{~W})$ portions of the field with Pioneer hybrid 3563 (susceptible to gray leaf spot).

Fungicide treatments differed among experiments. In fields 10, $8 \mathrm{E}$, and Conrad, there were seven treatments and in field $8 \mathrm{~W}$, there were nine treatments but only seven are reported here (Tables 2 and 3). All mancozeb applications included a spreader sticker, Latron CS7, at $168 \mathrm{ml} / \mathrm{ha}$. In addition to propiconazole and mancozeb, treatments in experiment $8 \mathrm{~W}$ included thiophanate-methyl (Topsin M WSB; Elf Atochem NA). Application details are shown in Tables 2 and 3. Disease symptoms were observed at the time of fungicide applications. In field 8, there were 
low levels of gray leaf spot and common rust (Puccinia sorghi) at the time of the first application and there were moderate levels of both diseases at the time of the second application. In field 10, gray leaf spot was present but there was little or no common rust. At Conrad, gray leaf spot was present at low severity and rust was absent at the time of the fungicide applications. Disease severity was assessed twice in each experiment, as previously described, except that diseased leaf area estimates were limited to the ear leaf. In each experiment, the middle six rows of each plot were harvested with a plot combine as previously described. Yields were calculated with corrections for moisture content (standardized to $15.5 \%$ ).

In 1997, we conducted two experiments: one experiment was at SERF and one was near Conrad. Two hybrids were planted at each location in a split-plot design with hybrids as main plots and fungicide treatments as subplots. The hybrids at SERF were Pioneer hybrids 3335 and 3489; the hybrids at Conrad were DK559 and Cargill 6303 (susceptible to gray leaf spot). There

TABLE 2. Effects of fungicides on gray leaf spot severity and maize yield in Iowa field experiments conducted in 1995 and 1996

\begin{tabular}{|c|c|c|c|c|c|c|c|c|}
\hline \multirow[b]{2}{*}{ Year } & \multirow[b]{2}{*}{ Experiment $^{\mathrm{v}}$} & \multirow[b]{2}{*}{ Hybrid $^{w}$} & \multirow[b]{2}{*}{ Fungicide } & \multirow[b]{2}{*}{ Rate (g a.i./ha) } & \multirow[b]{2}{*}{$\operatorname{Timing}^{\mathrm{x}}$} & \multicolumn{2}{|c|}{ Disease rating at $\mathrm{R} 5$} & \multirow[b]{2}{*}{ Yield (t/ha) } \\
\hline & & & & & & $\%$ Leaf area ${ }^{\mathrm{y}}$ & Plot rating ${ }^{\mathrm{z}}$ & \\
\hline \multirow[t]{5}{*}{1995} & SERF 1 & 3394 & None & $\ldots$ & $\ldots$ & $45.1 \mathrm{a}$ & $7.7 \mathrm{a}$ & $5.87 \mathrm{c}$ \\
\hline & & & Propiconazole once & 125 & 2 & $7.8 \mathrm{~b}$ & $4.7 \mathrm{~cd}$ & $7.52 \mathrm{a}$ \\
\hline & & & Propiconazole twice & 125 & 1,2 & $8.1 \mathrm{~b}$ & $4.0 \mathrm{~d}$ & $6.72 \mathrm{~b}$ \\
\hline & & & Mancozeb once & 1,260 & 2 & $35.7 \mathrm{a}$ & $7.3 \mathrm{ab}$ & $6.22 \mathrm{bc}$ \\
\hline & & & Mancozeb twice & 1,260 & 1,2 & $29.1 \mathrm{a}$ & $6.0 \mathrm{bc}$ & $6.48 \mathrm{bc}$ \\
\hline \multirow[t]{5}{*}{1995} & SERF 2 & 5677 & None & $\ldots$ & $\ldots$ & $22.1 \mathrm{a}$ & $7.0 \mathrm{a}$ & $\ldots$ \\
\hline & & & Propiconazole once & 125 & 2 & $6.0 \mathrm{~b}$ & $3.2 \mathrm{~b}$ & $\ldots$ \\
\hline & & & Propiconazole twice & 125 & 1,2 & $5.3 \mathrm{~b}$ & $3.2 \mathrm{~b}$ & $\ldots$ \\
\hline & & & Mancozeb once & 1,260 & 2 & $16.4 \mathrm{ab}$ & $4.7 \mathrm{~b}$ & $\ldots$ \\
\hline & & & Mancozeb twice & 1,260 & 1,2 & $13.9 \mathrm{ab}$ & $4.7 \mathrm{~b}$ & $\ldots$ \\
\hline \multirow[t]{5}{*}{1995} & Conrad & 3394 & None & $\ldots$ & $\ldots$ & $72.8 \mathrm{a}$ & $7.7 \mathrm{a}$ & $9.55 \mathrm{~b}$ \\
\hline & & & Propiconazole once & 125 & 2 & $24.7 \mathrm{~d}$ & $5.7 \mathrm{~d}$ & $10.83 \mathrm{a}$ \\
\hline & & & Propiconazole twice & 125 & 1,2 & $17.5 \mathrm{~d}$ & $4.5 \mathrm{e}$ & $10.84 \mathrm{a}$ \\
\hline & & & Mancozeb once & 1,260 & 2 & $49.0 \mathrm{~b}$ & $6.7 \mathrm{~b}$ & $9.51 \mathrm{~b}$ \\
\hline & & & Mancozeb twice & 1,260 & 1,2 & $39.3 \mathrm{c}$ & $6.0 \mathrm{c}$ & $9.52 \mathrm{~b}$ \\
\hline \multirow[t]{5}{*}{1995} & Mount Pleasant & DK591 & None & $\ldots$ & $\ldots$ & $4.7 \mathrm{a}$ & $3.0 \mathrm{a}$ & $\ldots$ \\
\hline & & & Propiconazole once & 125 & 2 & $2.7 \mathrm{~b}$ & $2.3 \mathrm{bc}$ & $\ldots$ \\
\hline & & & Propiconazole twice & 125 & 1,2 & $2.7 \mathrm{~b}$ & $2.2 \mathrm{c}$ & $\ldots$ \\
\hline & & & Mancozeb once & 1,260 & 2 & $5.7 \mathrm{a}$ & $2.8 \mathrm{ab}$ & $\ldots$ \\
\hline & & & Mancozeb twice & 1,260 & 1,2 & $4.0 \mathrm{ab}$ & $2.3 \mathrm{bc}$ & $\ldots$ \\
\hline \multirow[t]{14}{*}{1996} & SERF field 10 & 3348 & None & $\ldots$ & $\ldots$ & $2.6 \mathrm{a}$ & $3.0 \mathrm{a}$ & $9.80 \mathrm{a}$ \\
\hline & & & Propiconazole once & 125 & 2 & $<1 \mathrm{~b}$ & $1.5 \mathrm{~b}$ & $9.56 \mathrm{a}$ \\
\hline & & & Propiconazole twice & 125 & 1,2 & $<1 b$ & $1.2 \mathrm{~b}$ & $10.22 \mathrm{a}$ \\
\hline & & & Mancozeb once & 1,260 & 2 & $<1 \mathrm{~b}$ & $2.0 \mathrm{~b}$ & $9.90 \mathrm{a}$ \\
\hline & & & Mancozeb twice early & 1,260 & 1,2 & $<1 \mathrm{~b}$ & $1.6 \mathrm{~b}$ & $9.40 \mathrm{a}$ \\
\hline & & & Mancozeb twice late & 1,260 & 2,3 & $<1 \mathrm{~b}$ & $1.5 \mathrm{~b}$ & $9.51 \mathrm{a}$ \\
\hline & & & Propiconazole once, mancozeb once & $125 ; 1,260$ & 2,3 & $<1 \mathrm{~b}$ & $1.5 \mathrm{~b}$ & $9.63 \mathrm{a}$ \\
\hline & & 3394 & None & $\ldots$ & $\ldots$ & $8.4 \mathrm{a}$ & $5.5 \mathrm{a}$ & $9.55 \mathrm{~b}$ \\
\hline & & & Propiconazole once & 125 & 2 & $<1 \mathrm{c}$ & $2.5 \mathrm{~d}$ & $10.64 \mathrm{a}$ \\
\hline & & & Propiconazole twice & 125 & 1,2 & $<1 \mathrm{c}$ & $1.7 \mathrm{~d}$ & $10.62 \mathrm{a}$ \\
\hline & & & Mancozeb once & 1,260 & 2 & $1.8 \mathrm{bc}$ & $3.5 \mathrm{bc}$ & $9.51 \mathrm{~b}$ \\
\hline & & & Mancozeb twice early & 1,260 & 1,2 & $2.4 \mathrm{~b}$ & $3.9 \mathrm{~b}$ & $9.71 \mathrm{ab}$ \\
\hline & & & Mancozeb twice late & 1,260 & 2,3 & $<1 \mathrm{c}$ & $2.7 \mathrm{~cd}$ & $10.25 \mathrm{ab}$ \\
\hline & & & Propiconazole once, mancozeb once & $125 ; 1,260$ & 2,3 & $<1 \mathrm{c}$ & $2.1 \mathrm{~d}$ & $10.46 \mathrm{a}$ \\
\hline \multirow[t]{7}{*}{1996} & SERF field $8 \mathrm{E}$ & 3563 & None & $\ldots$ & $\ldots$ & $14.7 \mathrm{a}$ & $6.2 \mathrm{a}$ & $4.67 \mathrm{bc}$ \\
\hline & & & Propiconazole once & 125 & 2 & $2.6 \mathrm{~b}$ & $3.5 \mathrm{c}$ & $4.91 \mathrm{a}-\mathrm{c}$ \\
\hline & & & Propiconazole twice & 125 & 1,2 & $2.2 \mathrm{~b}$ & $3.2 \mathrm{c}$ & $5.22 \mathrm{a}$ \\
\hline & & & Mancozeb once & 1,260 & 2 & $17.4 \mathrm{a}$ & $6.2 \mathrm{a}$ & $4.66 \mathrm{bc}$ \\
\hline & & & Mancozeb twice early & 1,260 & 1,2 & $15.4 \mathrm{a}$ & $6.2 \mathrm{a}$ & $4.53 \mathrm{c}$ \\
\hline & & & Mancozeb twice late & 1,260 & 2,3 & $6.3 \mathrm{~b}$ & $4.5 \mathrm{~b}$ & $4.66 \mathrm{bc}$ \\
\hline & & & Propiconazole once, mancozeb once & $125 ; 1,260$ & 2,3 & $2.1 \mathrm{~b}$ & $2.0 \mathrm{~d}$ & $5.10 \mathrm{ab}$ \\
\hline \multirow[t]{7}{*}{1996} & SERF field $8 \mathrm{~W}$ & 3563 & None & $\ldots$ & $\ldots$ & $9.8 \mathrm{a}$ & $3.7 \mathrm{a}$ & $4.21 \mathrm{~b}$ \\
\hline & & & Propiconazole twice & 125 & 1,2 & $1.9 \mathrm{~b}$ & $1.7 \mathrm{~b}$ & $4.63 \mathrm{ab}$ \\
\hline & & & Propiconazole twice + mancozeb twice & $125 ; 1,260$ & $1,2,3,4$ & $1.9 \mathrm{~b}$ & $1.7 \mathrm{~b}$ & $4.50 \mathrm{ab}$ \\
\hline & & & Mancozeb $4 \times$ & 1,260 & $1,2,3,4$ & $5.2 \mathrm{~b}$ & $2.2 \mathrm{ab}$ & $4.43 \mathrm{ab}$ \\
\hline & & & Mancozeb + thiophanate M $4 \times$ & 1,$260 ; 392$ & $1,2,3,4$ & $1.8 \mathrm{~b}$ & $1.5 \mathrm{~b}$ & $5.05 \mathrm{a}$ \\
\hline & & & Thiophanate $\mathrm{M}$ twice & 784 & 1,2 & $2.9 \mathrm{~b}$ & $2.0 \mathrm{ab}$ & $4.73 \mathrm{ab}$ \\
\hline & & & Thiophanate $\mathrm{M} 4 \times$ & 784 & $1,2,3,4$ & $1.7 \mathrm{~b}$ & $1.5 \mathrm{~b}$ & $4.89 \mathrm{ab}$ \\
\hline
\end{tabular}

v SERF = Iowa State University Southeast Research Farm, Crawfordsville.

${ }^{w}$ All hybrids were provided by Pioneer Hi-Bred International Inc. (Des Moines, IA), except hybrids 5677 (Cargill Hybrid Seeds Inc.) and DK591 (DeKalb Plant Genetics, DeKalb, IL).

x 1 = stage V8 to V9 (growth stage descriptions) (24); 2 = stage V14 to VT; 3 = stage R1 to R2; and 4 = stage R3. For 1995, SERF and Mount Pleasant, $1=8$ July, $2=26$ July; 1995 Conrad, $1=3$ July, $2=24$ July; and SERF 8E and 8W, $1=19$ July, $2=6$ August, $3=20$ August, and $4=31$ August; and SERF field $10,1=9$ July, $2=23$ July, and $3=6$ August.

y Percentage of the ear leaf diseased (ear leaf and leaf above the ear in 1995) by visual assessment; mean of 10 plants per replication, three to six replications. Within a hybrid, values followed by the same letter are not significantly different according to Duncan's multiple range test $(\alpha=0.05)$. Results for hybrids in the same experiment were analyzed separately due to interactions.

${ }^{\mathrm{z}}$ Whole plot ratings in which $1=$ traces of disease, $5=$ disease present on most leaves with some lower leaves dead, and $9=$ nearly all leaf tissue killed. Values are means of three to six replications. Within a hybrid, values followed by the same letter are not significantly different according to Duncan's multiple range test $(\alpha=0.05)$. Results for hybrids in the same experiment were analyzed separately due to interactions. 
were 12 fungicide treatments but only 11 are reported here (Table 3). Disease symptoms were negligible at the time of the fungicide applications. Disease was assessed twice at SERF and once at Conrad as described for the 1996 experiments. Prior to harvest, plants in the buffer zones between plots were harvested by hand and the final plot lengths measured. Yields were measured only at SERF. The middle six rows of each plot were harvested with a plot combine (previously described). Grain weights and moisture content were measured on the combine. Yields were calculated with corrections for moisture content (standardized to $15.5 \%$ ).

Data analysis. Disease severity ratings and yields were analyzed by analysis of variance using the general linear models procedure of the SAS statistical software (SAS Institute, Cary, NC), and mean separation was performed with Duncan's multiple range test $(\alpha=0.05)$. In each experiment with two hybrids, there were significant interactions between the effects of fungicide treatment and hybrid on yield; therefore, data for each hybrid were analyzed separately. Linear correlation analysis was performed to describe the relationship between the two disease severity ratings and their relationship with yield. Correlation analysis was performed separately for each experiment and hybrid because of differences in overall mean yield among experiments and hybrids.

We performed analyses of economic benefits for the treatments involving one or two applications of propiconazole. The net return (D) per hectare for a particular fungicide treatment depended on the difference in yield between treated and nontreated plots $\left(\Delta_{y}=\bar{y}_{f}-\bar{y}_{c}\right)$, the price of grain $(R)$, the cost of fungicide application for a commercial producer, $C_{f}$ (estimated at $\$ 39 /$ ha per application), and the added cost of grain drying for a commercial producer, $C_{a}$, estimated at $\$ 0.79 /(1 \%$ moisture) (t) (6) because grain from fungicide-treated plots was typically higher in moisture than that from nontreated plots. Thus,

$$
D=\Delta_{y} R-\left(N C_{f}+\bar{y}_{f} d C_{a}\right)
$$

where $N$ is the number of fungicide applications (one or two), and $d$ is the difference in the percentage of grain moisture content between fungicide-treated and nontreated plots. Hence the yield difference, $\Delta_{y D}$, corresponding to a specific value of $D$ was calculated as

$$
\Delta_{y D}=\left(D+N C_{f}+\bar{y}_{f} d C_{a}\right) / R
$$

The probability, $P_{D}$, that a fungicide treatment resulted in a yield difference larger than a specified value $\left(\Delta_{y D}\right)$ (and thus, the probability that the treatment resulted in a net return larger than $D$ ) was calculated from the observed yield difference between treated and nontreated plots $\left(\bar{y}_{f}-\bar{y}_{c}\right)$ and the observed standard deviation in yield, $s$, using Bayesian statistical methods (2). In Bayesian inference, the yield difference for a particular experiment is considered to be a random variable. We assumed that prior to the experiment there was no information about the yield difference on each farm. In Bayesian terms, we used a noninformative prior distribution. The plot data from the experiment on each farm provided information about the distribution of the yield difference. This information is summarized as the posterior distribution of the yield difference. Under standard assumptions that the errors in observed yields are independently, normally distributed with equal variances, the posterior distribution of the yield difference is a rescaled and recentered Student's $t$ distribution (pages 103 to 104 in literature citation 2). That is, the quantity

$$
T\left(\Delta_{y D}\right)=\frac{\Delta_{y D}-\left(\bar{y}_{f}-\bar{y}_{c}\right)}{s \sqrt{1 / n_{f}+1 / n_{c}}}
$$

has a Student's $t$ distribution with the error degrees of freedom $\left(n_{f}\right.$ and $n_{c}$ are the numbers of observations for the fungicide-treated and control treatments). The probability that the net return exceeds $D$ is the same as the probability that the yield difference exceeds $\Delta_{y D}$. Both are calculated by computing $T\left(\Delta_{y D}\right)$, then using the SAS PROBT function to compute the 1-tailed probability

$$
P_{D}=1-\operatorname{PROBT}\left[T\left(\Delta_{y D}\right), d f_{e}\right]
$$

In the calculation for two applications of propiconazole, the prob-

\begin{tabular}{|c|c|c|c|c|c|c|c|c|c|}
\hline \multirow[b]{2}{*}{ Location } & \multirow[b]{2}{*}{ Fungicide } & \multirow[b]{2}{*}{ Rate (g a.i./ha) } & \multirow[b]{2}{*}{ Timing $^{\mathrm{w}}$} & \multicolumn{3}{|c|}{ Hybrid $3489^{x}$} & \multicolumn{3}{|c|}{ Hybrid $3335^{\mathrm{x}}$} \\
\hline & & & & $\%$ Leaf area ${ }^{\mathrm{y}}$ & Plot rating ${ }^{z}$ & Yield (t/ha) & $\%$ Leaf area ${ }^{\mathrm{y}}$ & Plot rating $\mathrm{z}$ & Yield (t/ha) \\
\hline \multirow{7}{*}{$\begin{array}{c}\text { Conrad } \\
1996\end{array}$} & None & $\ldots$ & $\ldots$ & $9.0 \mathrm{a}$ & $4.6 \mathrm{ab}$ & $10.89 \mathrm{~d}$ & $5.7 \mathrm{a}$ & $4.6 \mathrm{a}$ & $10.83 \mathrm{c}$ \\
\hline & Propiconazole once & 125 & 2 & $2.1 \mathrm{bc}$ & $3.8 \mathrm{~b}-\mathrm{d}$ & $11.41 \mathrm{bc}$ & $1.6 \mathrm{c}$ & $3.0 \mathrm{c}$ & $11.34 \mathrm{a}-\mathrm{c}$ \\
\hline & Propiconazole twice & 125 & 1,2 & $1.4 \mathrm{c}$ & $3.6 \mathrm{~cd}$ & $11.84 \mathrm{a}$ & $1.1 \mathrm{c}$ & $2.8 \mathrm{c}$ & $11.62 \mathrm{a}$ \\
\hline & Mancozeb once & 1,260 & 2 & $4.3 \mathrm{bc}$ & $4.8 \mathrm{a}$ & $10.87 \mathrm{c}$ & $4.0 \mathrm{~b}$ & $4.2 \mathrm{ab}$ & $10.97 \mathrm{c}$ \\
\hline & Mancozeb twice early & 1,260 & 1,2 & $5.9 \mathrm{ab}$ & $4.6 \mathrm{ab}$ & $11.08 \mathrm{bc}$ & $4.0 \mathrm{~b}$ & $4.0 \mathrm{ab}$ & $11.05 \mathrm{bc}$ \\
\hline & Mancozeb twice late & 1,260 & 2,3 & $4.9 \mathrm{bc}$ & $4.4 \mathrm{a}-\mathrm{c}$ & $11.10 \mathrm{bc}$ & $3.9 \mathrm{~b}$ & $3.8 \mathrm{~b}$ & $11.06 \mathrm{bc}$ \\
\hline & Propiconazole once, mancozeb once & $125 ; 1,260$ & 2,3 & $1.0 \mathrm{c}$ & $3.4 \mathrm{~d}$ & $11.65 \mathrm{ab}$ & $1.3 \mathrm{c}$ & $2.8 \mathrm{c}$ & $11.55 \mathrm{ab}$ \\
\hline \multirow{11}{*}{$\begin{array}{r}\text { SERF } \\
1997\end{array}$} & None & $\ldots$ & $\ldots$ & $19.9 \mathrm{a}$ & $5.4 \mathrm{a}$ & $7.92 \mathrm{a}$ & $7.7 \mathrm{a}$ & $4.2 \mathrm{a}$ & $6.34 \mathrm{a}$ \\
\hline & Propiconazole once & 125 & 2 & $12.5 \mathrm{~b}$ & $5.4 \mathrm{a}$ & $7.96 \mathrm{a}$ & $3.8 \mathrm{bc}$ & $3.8 \mathrm{ab}$ & $6.87 \mathrm{a}$ \\
\hline & Propiconazole twice early & 125 & 1,2 & $5.8 \mathrm{c}$ & $4.6 \mathrm{a}-\mathrm{d}$ & $7.95 \mathrm{a}$ & $1.8 \mathrm{~d}$ & $3.2 \mathrm{bc}$ & $6.24 \mathrm{a}$ \\
\hline & Propiconazole twice late & 125 & 2,3 & $3.9 \mathrm{c}$ & $4.4 \mathrm{~b}-\mathrm{d}$ & $8.43 \mathrm{a}$ & $4.5 \mathrm{~b}$ & $3.8 \mathrm{ab}$ & $7.07 \mathrm{a}$ \\
\hline & Propiconazole, mancozeb & 125 & 2,3 & $9.6 \mathrm{bc}$ & $5.0 \mathrm{ab}$ & $7.67 \mathrm{a}$ & $4.1 \mathrm{bc}$ & $3.8 \mathrm{ab}$ & $6.93 \mathrm{a}$ \\
\hline & Thiophanate M, mancozeb & $392 ; 1,260$ & 2,3 & $7.4 \mathrm{bc}$ & $4.6 \mathrm{a}-\mathrm{d}$ & $7.83 \mathrm{a}$ & $1.9 \mathrm{~d}$ & $3.4 \mathrm{bc}$ & $6.81 \mathrm{a}$ \\
\hline & Thiophanate $\mathrm{M}+$ mancozeb twice & $392+1,260$ & 2,3 & $4.4 \mathrm{c}$ & $4.0 \mathrm{~cd}$ & $8.16 \mathrm{a}$ & $1.5 \mathrm{~d}$ & $3.2 \mathrm{bc}$ & $6.82 \mathrm{a}$ \\
\hline & Thiophanate $\mathrm{M}+$ mancozeb twice & $294+1,260$ & 2,3 & $4.2 \mathrm{c}$ & $4.0 \mathrm{~cd}$ & $7.87 \mathrm{a}$ & $2.5 \mathrm{~cd}$ & $3.6 \mathrm{a}-\mathrm{c}$ & $6.97 \mathrm{a}$ \\
\hline & Thiophanate $\mathrm{M}$ once & 392 & 2 & $7.7 \mathrm{bc}$ & $4.8 \mathrm{a}-\mathrm{c}$ & $7.58 \mathrm{a}$ & $1.9 \mathrm{~d}$ & $3.4 \mathrm{bc}$ & $6.65 \mathrm{a}$ \\
\hline & Thiophanate $\mathrm{M}$ twice & 392 & 2,3 & $5.2 \mathrm{c}$ & $4.0 \mathrm{~cd}$ & $7.90 \mathrm{a}$ & $1.3 \mathrm{~d}$ & $3.0 \mathrm{c}$ & $7.03 \mathrm{a}$ \\
\hline & Thiophanate $\mathrm{M}$ twice & 392 & 1,2 & $3.7 \mathrm{c}$ & $3.8 \mathrm{~d}$ & $7.82 \mathrm{a}$ & $1.5 \mathrm{~d}$ & $3.2 \mathrm{bc}$ & $6.36 \mathrm{a}$ \\
\hline
\end{tabular}
ability was calculated for net return on both applications together, instead of each application separately. This approach was used

TABLE 3. Effects of fungicides on gray leaf spot severity and maize yield in Iowa field experiments conducted in 1996 and 1997

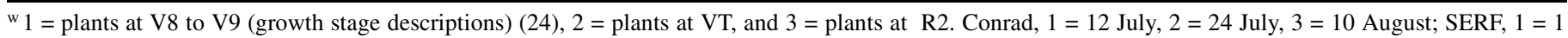
July, $2=25$ July, and $3=14$ August.

x Pioneer Hi-Bred International Inc. (Des Moines, IA).

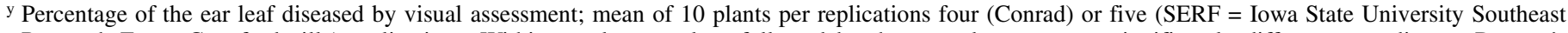
Research Farm, Crawfordsville) replications. Within a column, values followed by the same letter are not significantly different according to Duncan's multiple range test $(\alpha=0.05)$. Results for hybrids in the same experiment were analyzed separately due to interactions.

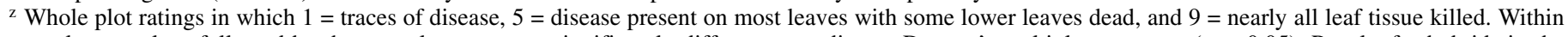
a column, values followed by the same letter are not significantly different according to Duncan's multiple range test ( $\alpha=0.05$ ). Results for hybrids in the same experiment were analyzed separately due to interactions. Values are means of four (Conrad) or five (SERF) replications. 
because the two-application regime included an earlier application (growth stage V8) (24) than the single application regime. Therefore a decision to use two applications would be made prior to the first application, and the probability for a positive net return should be considered for the fungicide program as a whole instead of for each application.

This method was used to calculate the probability of returns equaling or exceeding costs $(D \geq 0$ or break-even point) for one or two propiconazole applications in each experiment. Probabilities were calculated for grain prices $(R)$ equal to $\$ 79, \$ 99$, and $\$ 118 / \mathrm{t}$ $(\$ 2.00, \$ 2.50$, and $\$ 3.00$ per bushel). In addition, the probability of net return equaling or exceeding $\$ 25 / \mathrm{ha}(D=25)$ was calculated to demonstrate a profit level a producer might arbitrarily set as a criterion that would justify a fungicide application.

\section{RESULTS}

Preliminary disease severity and yield results have been reported (20). Gray leaf spot was the predominant foliar disease in every experiment, although traces of common rust (Puccinia sorghi), Stewart's disease (Pantoea stewartii), and northern leaf spot (Bipolaris zeicola) occurred in some experiments. The highest gray leaf spot severity occurred in the 1995 experiments at SERF and Conrad, whereas the 1995 experiment at Mount Pleasant had low gray leaf spot severity. Both experiments in 1997 had low disease severity. Gray leaf spot severity on the ear leaf in untreated control plots ranged from $2.6 \%$ on Pioneer hybrid 3348 at SERF in 1996 to $72.8 \%$ on Pioneer hybrid 3394 at Conrad in 1995. Whole-plot disease severity ratings in untreated control plots ranged from 3.0 to 7.7. Only traces of gray leaf spot were observed at Conrad in 1997 (data not shown). In each experiment, fungicide applications significantly reduced gray leaf spot severity (Tables 2 and 3). Propiconazole provided better disease control than mancozeb. In most cases, disease severity was numerically lower with two applications of propiconazole than with one, but this difference usually was not statistically significant. Thiophanate-methyl was included in two experiments alone or in combination with mancozeb. In comparable treatments, disease severity was usually numerically lower with thiophanate-methyl than with propiconazole, but this difference usually was not significant.

There was a significant $(P<0.01)$ linear correlation between diseased leaf area estimates and whole-plot ratings for every experiment (Table 4). The correlation coefficients typically were highest (up to 0.97 ) in experiments with high disease severity and lower $(\geq 0.47)$, but still significant, in experiments with lower disease severity. There were significant $(P<0.05)$ correlations between gray leaf spot severity and yield (Table 4) for every experiment in which yield was measured, except the 1997 experiment at SERF, where severe lodging affected the yields. In 1996, there was a significant correlation between gray leaf spot severity and yield for hybrid 3394 but not for the more resistant hybrid 3348.

Yields were highest in the 1996 Conrad experiment and lowest in the 1996 experiments in field 8 at SERF. Yields ranged from $4.21 \mathrm{t} / \mathrm{ha}$ for the control treatment in field $8 \mathrm{~W}$ to $11.84 \mathrm{t} / \mathrm{ha}$ for two applications of propiconazole at Conrad. Fungicide treatment significantly $(P \leq 0.05)$ affected yield in each experiment in which yield was measured (Tables 2 and 3), except the 1997 SERF experiment. Yield increase with a single application of propiconazole exceeded $0.5 \mathrm{t} / \mathrm{ha}$ for at least one hybrid in five of the seven experiments in which yield was measured. The greatest yield increase was $1.65 \mathrm{t} / \mathrm{ha}$ for the propiconazole treatment at SERF in 1995. We assumed that yield would not have been affected at Mount Pleasant in 1995 and Conrad in 1997 because of the low gray leaf spot severity in these experiments; however, we did not measure yield in those two locations. The highest yields tended to occur with two applications of propiconazole, but this treatment frequently was not significantly different from the single propiconazole application (Tables 2 and 3 ).

In some experiments there was a significant $(P \leq 0.05)$ effect of fungicide treatment on grain moisture at harvest. Treatments with the lowest disease severity had the highest grain moisture content (data not shown).

Probabilities for achieving a positive net return with a single fungicide application ranged from approximately 0.06 to more than 0.99 (Table 5). For two applications, this probability ranged from approximately 0.04 to 0.96 . Probabilities for achieving a net return of $\$ 25 /$ ha ranged from less than 0.02 to approximately 0.98 for a single application, and from less than 0.01 to approximately 0.88 for two applications. The highest probabilities occurred in the 1995 SERF and Conrad experiments (hybrid 3394), and the lowest occurred in the 1996 experiments in field 8E and field 10 (hybrid 3348). Probabilities were almost always higher for a single application of propiconazole than for two applications.

\section{DISCUSSION}

This research has demonstrated that fungicide applications can be used profitably to manage gray leaf spot in maize grown for grain in Iowa. The probability of a positive net return on a single propiconazole application exceeded 0.50 in six of nine scenarios (specific experiment per hybrid). The likelihood of profitability was almost always greater for a single application, because in these experiments yields were very similar with one or two applications of propiconazole. Therefore, in every scenario except one, the use of two applications decreased the probability of achieving a positive net return on the fungicide program compared with the use of a single application. The exception was hybrid 3348 in

TABLE 4. Linear correlation coefficients for two different gray leaf spot severity rating methods and yield for field experiments in Iowa, 1995 to 1997

\begin{tabular}{|c|c|c|c|c|c|}
\hline Experiment $^{\mathrm{w}}$ & Hybrid $^{\mathrm{x}}$ & $n$ & Variable $^{y}$ & Plot rating $\mathrm{z}$ & Yield $^{\mathrm{z}}$ \\
\hline 1995 SERF 1 & 3394 & $\begin{array}{l}15 \\
15\end{array}$ & $\begin{array}{l}\text { Leaf area } \\
\text { Plot rating }\end{array}$ & $0.90 * *$ & $\begin{array}{l}-0.66^{* *} \\
-0.74^{* *}\end{array}$ \\
\hline 1995 SERF 2 & 5677 & $\begin{array}{l}20 \\
20\end{array}$ & $\begin{array}{l}\text { Leaf area } \\
\text { Plot rating }\end{array}$ & $0.89 * *$ & $\begin{array}{l}\text { ND } \\
\text { ND }\end{array}$ \\
\hline 1995 Conrad & 3394 & $\begin{array}{l}30 \\
30\end{array}$ & $\begin{array}{l}\text { Leaf area } \\
\text { Plot rating }\end{array}$ & $0.97 * *$ & $\begin{array}{l}-0.84^{* *} \\
-0.81 * *\end{array}$ \\
\hline 1995 Mt. Pleasant & DK591 & $\begin{array}{l}30 \\
30\end{array}$ & $\begin{array}{l}\text { Leaf area } \\
\text { Plot rating }\end{array}$ & $0.47 * *$ & $\begin{array}{l}\text { ND } \\
\text { ND }\end{array}$ \\
\hline 1996 SERF field 10 & 3348 & $\begin{array}{l}28 \\
28\end{array}$ & $\begin{array}{l}\text { Leaf area } \\
\text { Plot rating }\end{array}$ & $0.77 * *$ & $\begin{array}{l}-0.11 \\
-0.19\end{array}$ \\
\hline 1996 SERF field 10 & 3394 & $\begin{array}{l}28 \\
28\end{array}$ & $\begin{array}{l}\text { Leaf area } \\
\text { Plot rating }\end{array}$ & $0.84 * *$ & $\begin{array}{l}-0.41^{*} \\
-0.50^{* *}\end{array}$ \\
\hline 1996 SERF field 8E & 3563 & $\begin{array}{l}42 \\
42\end{array}$ & $\begin{array}{l}\text { Leaf area } \\
\text { Plot rating }\end{array}$ & $0.87 * *$ & $\begin{array}{l}-0.38^{*} \\
-0.34 *\end{array}$ \\
\hline 1996 SERF field 8W & 3563 & $\begin{array}{l}36 \\
36\end{array}$ & $\begin{array}{l}\text { Leaf area } \\
\text { Plot rating }\end{array}$ & $0.65 * *$ & $\begin{array}{l}-0.41 * * \\
-0.39 *\end{array}$ \\
\hline 1996 Conrad & 3335 & $\begin{array}{l}35 \\
35\end{array}$ & $\begin{array}{l}\text { Leaf area } \\
\text { Plot rating }\end{array}$ & $0.80 * *$ & $\begin{array}{l}-0.47^{* *} \\
-0.55^{* *}\end{array}$ \\
\hline 1996 Conrad & 3489 & $\begin{array}{l}35 \\
35\end{array}$ & $\begin{array}{l}\text { Leaf area } \\
\text { Plot rating }\end{array}$ & $0.70 * *$ & $\begin{array}{l}-0.42 * \\
-0.41 *\end{array}$ \\
\hline 1997 SERF & 3335 & $\begin{array}{l}60 \\
60\end{array}$ & $\begin{array}{l}\text { Leaf area } \\
\text { Plot rating }\end{array}$ & $0.94 * *$ & $\begin{array}{r}-0.10 \\
0.11\end{array}$ \\
\hline 1997 SERF & 3489 & $\begin{array}{l}60 \\
60\end{array}$ & $\begin{array}{l}\text { Leaf area } \\
\text { Plot rating }\end{array}$ & $0.86 * *$ & $\begin{array}{l}-0.26 \\
-0.23\end{array}$ \\
\hline
\end{tabular}

${ }^{\mathrm{w}} \mathrm{SERF}=$ Iowa State University Southeast Research Farm, Washington County.

x All hybrids provided by Pioneer Hi-Bred International Inc., except hybrid 5677 (Cargill Hybrid Seeds Inc.) and hybrid DK591 (DeKalb Plant Genetics).

${ }^{\mathrm{y}}$ Leaf area $=$ percentage of leaf area diseased on the ear leaf (and the leaf above the ear leaf in 1995). Observations used in the analysis were the means of 10 arbitrarily chosen leaves per plot.

${ }^{\mathrm{z}}$ Plot rating $=$ whole plots were given a score of 1 to 9 in which $1=$ traces of disease, $5=$ disease present on most leaves with some lower leaves dead, and $9=$ nearly all leaf tissue killed. * Indicates correlation coefficient significant at $P<0.05$; ** indicates correlation coefficient significant at $P<0.01$. $\mathrm{ND}=$ not determined. 
1996, but in this case, all the probabilities were well below 0.50 and fungicide use was unlikely to be profitable. Based on these results, recommendations for control of gray leaf spot on maize grown for grain in Iowa should include, at most, one fungicide application, unless grain prices exceed $\$ 99 / \mathrm{t}$ ( $\$ 2.50$ per bushel). Regarding profitability of two applications, other studies in the United States do not present a clear picture. In Virginia and Kentucky in 1997 and in Virginia and Ohio in 1998, two applications of azoxystrobin did not result in yields significantly different from one application $(15,31,32,35)$, although with two applications in Virginia and Ohio, the yields were numerically higher by 0.5 to $1.1 \mathrm{t} / \mathrm{ha}$. Conversely, in Virginia in 1998, two applications of propiconazole significantly increased yield (1.6 t/ha) compared with a single application (32). Our results are not directly comparable with most of these studies because of differences in fungicides, application methods, or timing.

The probability of a profitable fungicide application, by definition, is linked to the magnitude of the yield difference between the treated and untreated plots, which is affected by overall yield potential, hybrid resistance and tolerance, and disease level. In 1996, the probabilities were very low in field 8 because of low yield potential due to late planting. The low overall yield potential made this field a poor candidate for profitable fungicide use. In field 10 in 1996, yield of hybrid 3348 apparently was not affected by fungicide application because of the relative resistance of this hybrid to gray leaf spot. In the same experiment, probability of a profitable fungicide application on susceptible hybrid 3394 was 0.88 or higher. These results support the high priority of hybrid selection as a primary tactic for gray leaf spot management. Fungicide use should be considered only for the more susceptible hybrids. The probability of a profitable fungicide application also is obviously linked to grain prices. The effect of grain price on the probabilities was greatest for those scenarios in which probabilities were less than 0.50 for the lowest grain price. Specialized, value-added maize crops that bring a higher price should have a higher probability for profitable fungicide use. Fungicides could be a particularly valuable tool in the management of these crops.

Whereas it is intuitive that the probability of profitable fungicide application is affected by hybrid susceptibility and grain price, the added contribution of the method used here is to assign a specific value to that probability. This perspective for evaluating the results of the fungicide experiments provides a more complete picture than reporting the mean yields and mean separation results. Mean separation results do not quantitatively describe the uncertainty associated with treatment means and can lead to misinterpretations. For example, a crop manager attempting to evaluate the results of a fungicide experiment would have difficulty drawing conclusions about treatments in which a yield increase that appeared sufficient to exceed the break-even point $(D \geq 0)$ was not significant according to a mean separation test. Equally perplexing is the situation in which two means are very similar but only one is significantly different from the control treatment. Mean separation results can indicate whether there is statistical evidence that a fungicide treatment increased yield compared with an untreated control, but cannot indicate the probability that the yield increase was sufficient to offset the cost of the fungicide treatment. With the method described here, it is possible to calculate this probability or the probability of achieving any given yield increase. If experimental results were reported with probabilities for $D \geq 0$ instead of simple mean separation, one could assess quantitatively the likelihood of a profitable treatment at prevailing prices. For example, in the 1996 Conrad experiment, yield for the single application of propiconazole exceeded the yield of the control by $0.51 \mathrm{t} / \mathrm{ha}$ (hybrid 3335) and $0.52 \mathrm{t} / \mathrm{ha}$ (hybrid 3489). This difference was significant for hybrid 3489 but not for hybrid 3335. In both cases, the yield increase would appear to be sufficient to offer a positive net return at a grain price of $\$ 79 / \mathrm{t}$ or more. However, based on mean separation results, one might conclude that the treatment was profitable for hybrid 3489, for which the yield gain was significant according to mean separation, but not for hybrid 3335, for which it was not significant. Instead, the probabilities indicate that in both cases the probability of a profitable application was nearly identical ( 0.53 and 0.54 , respectively). At a grain price of $\$ 79 / \mathrm{t}$, the break-even point for a single propiconazole application would be approximately $0.50 \mathrm{t} / \mathrm{ha}$. In our experiments, when the yield increase with a single application was near $0.50 \mathrm{t} / \mathrm{ha}$, the probability of a positive net return was approximately 0.50 , regardless of whether the yield increase was significant according to mean separation.

Bayesian inference methods are often used in human and veterinary epidemiology $(12,23)$, genetics $(8,40)$, and in ecological studies (4), and have been used in the management of insects (7). Tari (33) used a Bayesian network to predict the yield benefits of fungicide applications in winter wheat in the United Kingdom.

TABLE 5. Probability of profitability for one or two applications of propiconazole for hybrids evaluated in field experiments in Iowa, 1995 to $1997^{\mathrm{w}}$

\begin{tabular}{|c|c|c|c|c|c|c|c|c|}
\hline \multirow[b]{2}{*}{ Application } & \multirow[b]{2}{*}{ Experiment $^{\mathrm{x}}$} & \multirow[b]{2}{*}{ Hybrid $^{y}$} & \multicolumn{3}{|c|}{ Net return $=\$ 0 /$ ha "break-even point"z } & \multicolumn{3}{|c|}{ Net return $=\$ 25 / \mathrm{ha}^{\mathrm{z}}$} \\
\hline & & & $\$ 79 / \mathrm{t}$ & $\$ 99 / \mathrm{t}$ & $\$ 118 / \mathrm{t}$ & $\$ 79 / \mathrm{t}$ & $\$ 99 / \mathrm{t}$ & $\$ 118 / \mathrm{t}$ \\
\hline \multirow[t]{9}{*}{ One } & 1995 SERF 1 & 3394 & 0.979 & 0.984 & 0.986 & 0.951 & 0.969 & 0.977 \\
\hline & 1995 Conrad & 3394 & 0.981 & 0.989 & 0.992 & 0.910 & 0.960 & 0.977 \\
\hline & 1996 SERF field 8E & 3563 & 0.144 & 0.255 & 0.352 & 0.016 & 0.053 & 0.111 \\
\hline & 1996 SERF field 10 & 3348 & 0.062 & 0.086 & 0.107 & 0.022 & 0.037 & 0.054 \\
\hline & & 3394 & 0.881 & 0.912 & 0.928 & 0.719 & 0.816 & 0.865 \\
\hline & 1996 Conrad & 3335 & 0.531 & 0.680 & 0.770 & 0.115 & 0.284 & 0.451 \\
\hline & & 3489 & 0.538 & 0.724 & 0.820 & 0.081 & 0.256 & 0.453 \\
\hline & 1997 SERF & 3335 & 0.532 & 0.657 & 0.731 & 0.181 & 0.343 & 0.478 \\
\hline & & 3489 & 0.079 & 0.129 & 0.175 & 0.016 & 0.037 & 0.064 \\
\hline \multirow[t]{10}{*}{ Two } & 1995 SERF 1 & 3394 & 0.349 & 0.540 & 0.664 & 0.142 & 0.306 & 0.466 \\
\hline & 1995 Conrad & 3394 & 0.802 & 0.918 & 0.957 & 0.470 & 0.759 & 0.884 \\
\hline & 1996 SERF field 8E & 3563 & 0.039 & 0.150 & 0.310 & 0.004 & 0.027 & 0.093 \\
\hline & 1996 Serf field 8W & 3563 & 0.054 & 0.131 & 0.225 & 0.124 & 0.240 & 0.351 \\
\hline & 1996 SERF field 10 & 3348 & 0.105 & 0.197 & 0.286 & 0.037 & 0.090 & 0.157 \\
\hline & & 3394 & 0.563 & 0.719 & 0.801 & 0.308 & 0.521 & 0.664 \\
\hline & 1996 Conrad & 3335 & 0.192 & 0.479 & 0.692 & 0.026 & 0.144 & 0.357 \\
\hline & & 3489 & 0.376 & 0.754 & 0.902 & 0.043 & 0.286 & 0.624 \\
\hline & 1997 SERF & 3335 & 0.191 & 0.404 & 0.575 & 0.042 & 0.153 & 0.314 \\
\hline & & 3489 & 0.070 & 0.181 & 0.309 & 0.014 & 0.054 & 0.129 \\
\hline
\end{tabular}

${ }^{\text {w }}$ Probabilities were calculated based on the difference in yield between fungicide-treated and nontreated plots, using a Bayesian inference method.

${ }^{x}$ SERF = Iowa State University Southeast Research Farm, Washington County.

y All hybrids were from Pioneer Hi-Bred International Inc.

${ }^{\mathrm{z}}$ Grain prices: $\$ 79 / \mathrm{t}$, $\$ 99 / \mathrm{t}$, and $\$ 118 / \mathrm{t}$ correspond to $\$ 2.00, \$ 2.50$, and $\$ 3.00$ per bushel, respectively. 
Over $90 \%$ of winter wheat in the United Kingdom was routinely sprayed with a fungicide, and the Bayesian method was used to calculate the probabilities of various yield increases according to fungicide application timing. Tari (33) showed that the highest probabilities for the greatest yield increase were associated with three fungicide applications and confirmed the optimal timing for a single application but did not assess the profitability of the treatments. We are not aware of previously published applications of Bayesian inference methods in disease management in maize.

The two disease severity rating methods were highly correlated with each other and their correlation coefficients with yield were similar. The leaf area method is theoretically more precise but much more time-consuming than the whole-plot method, and because it did not demonstrate superior performance, it is difficult to recommend the leaf area method for fungicide studies. The correlations between disease severity and yield were quite variable among experiments, indicating that in some experiments gray leaf spot was not a major factor influencing yield variability. In some experiments, other factors affecting yield were obvious. At SERF in 1997, a high incidence of lodging occurred in some plots, and this had a greater influence on yield variability than gray leaf spot did. In 1996 at SERF, both experiments in field 8 were planted very late, resulting in very low yields throughout the experiment. As expected, the correlation between disease severity and yield was higher in the experiments that had higher disease severity.

Although gray leaf spot can affect lodging of maize plants $(13,38)$, in this study we did not observe lodging that was attributable to the disease. For this reason, we adjusted yield calculations to compensate for plants that lodged due to wind or damage by field equipment. In the experiment at SERF in 1997, this tactic was not very successful due to the high incidence of lodging.

Timing of fungicide applications can influence their efficacy (37) and therefore their profitability. In this study, we did not explore different timing of the applications. In South Africa, optimal timing of single applications for gray leaf spot occurred when disease was evident only on the basal five leaves and represented 2 to $3 \%$ of the total leaf area. This occurred after anthesis (growth stage VT to R1) (24) in three of four experiments. Applications made at or near this time appeared to be profitable in each experiment. The relevance of these results to the U.S. Corn Belt is uncertain because of the substantial differences in gray leaf spot severity, length of growing season, and maize plant development rates between the two continents. Previous work in maize seed production in Iowa (18) suggested that optimal timing for one application is at stage VT (tasseling) and for two applications at stages V7-V8 and VT. We followed this schedule in our experiments. Until 1999, only mancozeb was registered in the United States for application to maize after stage R1. Therefore, we did not extensively investigate applications of propiconazole after VT.

The major limitation in making fungicide application decisions for gray leaf spot is the inability to predict disease severity, and therefore, yield impact of the disease. Decision tools must be developed to predict the need for and optimal timing of fungicide applications for gray leaf spot. A simple EIL would not be adequate, as demonstrated by our 1995 results. Gray leaf spot severities at both SERF and Mount Pleasant at the time of the VT-stage fungicide application were well below $1 \%$ on a whole plant basis, but the subsequent rate of disease development at SERF was much higher, resulting in a damaging epidemic, whereas the disease progressed very little at Mount Pleasant. Although early season disease levels may have some value in predicting the probability of a profitable fungicide application, this may require very intense scouting and must be coupled with other variables that are related to subsequent rate of disease development. Current recommendations for gray leaf spot fungicide applications include consideration of hybrid susceptibility, agronomic practices, field history, and a disease threshold (19), but these factors are considered only qualitatively. A quantitative disease-severity prediction model would greatly improve growers' ability to efficiently use fungicides for gray leaf spot management. Research efforts are under way in this area (1).

\section{ACKNOWLEDGMENTS}

This research was partially funded by Novartis Crop Protection, Greensboro, NC, and Elf Atochem NA Inc., Philadelphia, PA. Journal Paper J-19043 of the Iowa Agriculture and Home Economics Experiment Station, Ames, Project 6514, supported by Hatch Act and State of Iowa funds. We thank K. VanDee, superintendent of the Iowa State University Southeast Research Farm, S. Holl, and M. Fitzpatrick for their cooperation and assistance with field experiments; W. M. Carlton and M. Agudela for their valuable technical assistance; and P. Vincelli, University of Kentucky, for critical review of the manuscript.

\section{LITERATURE CITED}

1. Bhatia, A., and Munkvold, G. P. 1999. Progress toward forecasting gray leaf spot severity on corn. (Abstr.) Phytopathology 89(suppl.):S104.

2. Box, G. E. P., and Tiao, G. C. 1973. Bayesian Inference in Statistical Analysis. Addison-Wesley, Reading, MA.

3. Coates, S. T., and White, D. G. 1994. Sources of resistance to gray leaf spot of corn. Plant Dis. 78:1153-1155.

4. Cullinan, V. I., Simmons, M. A., and Thomas, J. M. 1997. A Bayesian test of hierarchy theory: Scaling up variability in plant cover from field to remotely sensed data. Landsc. Ecol. 12:273-285.

5. Donahue, P. J., Stromberg, E. L., and Myers, S. L. 1991. Inheritance of reaction to gray leaf spot in a diallel cross of 14 maize inbreds. Crop Sci. 31:926-931.

6. Edwards, W., Smith, D., McLees, B., and Baitinger, J. 2000. 2000 Iowa farm custom rate survey. Iowa State Univ. Exten. Publ. FM-1698.

7. Foster, R. E., Tollefson, J. J., Nyrop, J. P., and Hein, G. L. 1986. Value of adult corn rootworm (Coleoptera: Chrysomelidae) population estimates in pest management decision making. J. Econ. Entomol. 79:303-310.

8. George, A. W., Mengersen, K. L., and Davis, G. P. 2000. Localization of a quantitative trait locus via a Bayesian approach. Biometrics 56:40-51.

9. Gorman, D., Anderson, B. M., and Abad, L. 1997. Yield loss of corn hybrids with differing levels of gray leaf spot resistance. Pages 171-182 in: Proc. Annu. Corn Sorghum Res. Conf., 52nd.

10. Huff, C. A., Ayers, J. E., and Hill, R. R. 1988. Inheritance of resistance in corn (Zea mays L.) to gray leaf spot. Phytopathology 78:790-794.

11. Jenco, J. H. 1995. Epidemiology of Cercospora zeae-maydis on Zea mays in Iowa. M.S. thesis. Iowa State University.

12. Knorr, H. L., and Rasser, G. 2000. Bayesian detection of clusters and discontinuities in disease maps. Biometrics 56:13-21.

13. Lipps, P. E. 1998. Gray leaf spot: A global threat to corn production. Online publication. APSNet Feature, Published by The American Phytopathological Society, St. Paul, MN.

14. Lipps, P. E., and Johnston, A. L. 1998. Control of gray leaf spot on corn with fungicides in Ohio, 1996. Fungic. Nematic. Tests 53:287.

15. Lipps, P. E., and Johnston, A. L. 1999. Control of gray leaf spot on hybrid corn with fungicides in Ohio, 1998. Fungic. Nematic. Tests 54:352-353.

16. Lipps, P. E., and Madden, L. V. 1992. Corn yield loss to moderate severities of gray leaf spot in Ohio. (Abstr.) Phytopathology 82(suppl.): S1107.

17. Lipps, P. E., Thomison, P. R., and Pratt, R. C. 1996. Reaction of corn hybrids to gray leaf spot. Pages 163-180 in: Proc. Annu. Corn Sorghum Res. Conf., 51 st.

18. Martinson, C. A., Wegulo, S. N., Rivera, C. J. M., and Nutter, F. W. 1995. Fungicidal spray program for seed corn production. Pages 71-79 in: Proc. Annu. Corn Sorghum Res. Conf., 49th.

19. Munkvold, G. P. 1998. Controlling gray leaf spot in field corn. Integr. Crop Mngmnt. 480:129-130.

20. Munkvold, G. P., and Martinson, C. A. 1998. Benefits of fungicide application for gray leaf spot on hybrid corn in Iowa. (Abstr.). Phytopathology 88(suppl.):S116.

21. Nutter, F. W., Jr., and Litwiler, D. 1998. A computer program to generate standard area diagrams to aid raters in assessing disease severity. (Abstr.) Phytopathology 88(suppl.):S117

22. Pedigo, L. P. 1999. Entomology and Pest Management. Prentice Hall, Upper Saddle River, NJ.

23. Richardson, S., and Gilks, W. R. 1993. A Bayesian approach to measurement error problems in epidemiology using conditional independence 
models. Am. J. Epidemiol. 138:430-442.

24. Ritchie, J. W., and Hanway, J. J. 1984. How a corn plant develops. Iowa State Univ. Spec. Rep. 48.

25. Saghai Maroof, M. A., Zue, Y. G., Ziang, Z. X., Stromberg, E. L., and Rufener, G. K. 1996. Identification of quantitative trait loci controlling resistance to gray leaf spot disease in maize. Theor. Appl. Genet. 93: 539-546.

26. Shaner, G., and Buechley, G. 1999. Effect of fungicides on gray leaf spot, 1998. Fungic. Nematic. Tests 54:354.

27. Shaner, G., Buechley, G., and Johnson, R. 1999. Effect of fungicides on seed corn, 1998. Fungic. Nematic. Tests 54:355-358.

28. Smith, K. L. 1989. Epidemiology of gray leaf spot of field corn (Zea mays L.) caused by Cercospora zeae-maydis Tehon \& Daniels. Ph.D. diss. University of Maryland, College Park.

29. Sparks, V. D. 1997. Managing gray leaf spot with hybrid resistance and patented technology. Pages 299-311 in: Proc. Annu. Corn Sorghum Res. Conf., 52nd.

30. Stromberg, E. L., and Flinchum, L. E. 1993. Evaluation of foliar fungicides for the control of gray leaf spot disease on corn in Virginia, 1992. Fungic. Nematic. Tests 48:207.

31. Stromberg, E. L., and Flinchum, L. E. 1998. Evaluation of foliar fungicides for the control of gray leaf spot disease on corn in Virginia, 1997. Fungic. Nematic. Tests 53:143-144.
32. Stromberg, E. L., and Flinchum, L. E. 1999. Evaluation of foliar fungicides for the control of gray leaf spot of corn in Virginia, 1998. Fungic. Nematic. Tests 54:359-360.

33. Tari, F. 1996. A Bayesian network for predicting yield response of winter wheat to fungicide programmes. Comp. Elec. Agric. 15:111-121.

34. Vincelli, P., and Doney, J. C., Jr. 1995. Yield loss assessment for gray leaf spot using Tilt fungicide, 1994. Fungic. Nematic. Tests 50:214.

35. Vincelli, P., and Henson, G. 1998. Evaluation of efficacy and yield effects of Tilt for gray leaf spot of corn, 1997. Fungic. Nematic. Tests $53: 145$.

36. Ward, J. M. J., Laing, M. D., and Nowell, D. C. 1997. Chemical control of gray leaf spot. Crop Prot. 16:265-271.

37. Ward, J. M. J., Laing, M. D., and Rijkenberg, F. H. J. 1997. Frequency and timing of fungicide applications for the control of gray leaf spot in maize. Plant Dis. 81:41-48.

38. Ward, J. M. J., Stromberg, E. L., Nowell, D. C., and Nutter, F. W., Jr. 1999. Gray leaf spot: A disease of global importance in maize production. Plant Dis. 83:884-895.

39. Wegulo, S. N., Martinson, C. A., Rivera-C., J. M., and Nutter, F. W. 1997. Model for economic analysis of fungicide usage in hybrid seed corn production. Plant Dis. 81:415-422.

40. Zhivitovsky, L. A. 1999. Estimating population structure in diploids with multilocus dominant DNA markers. Mol. Ecol. 8:907-913. 